No 4069

Studia nad Autorytaryzmem i Totalitaryzmem 43, nr 2

Wrocław 2021

https://doi.org/10.19195/2300-7249.43.2.4

PIOTR KIMLA

ORCID: 0000-0002-3346-8748

Uniwersytet Jagielloński

piotr.kimla@uj.edu.pl

\title{
Zbigniew Brzeziński a John Mearsheimer - dwie wizje rozwoju stosunków chińsko-amerykańskich
}

Słowa kluczowe: Zbigniew Brzeziński, John Mearsheimer, stosunki chińsko-amerykańskie, komunizm, liberalizm, realizm ofensywny, ewolucja stanowiska Brzezińskiego wobec Chin, możliwość wojny amerykańsko-chińskiej.

\section{ZBIGNIEW BRZEZIŃSKI AND JOHN MEARSHEIMER: TWO VISIONS OF THE DEVELOPMENT OF SINO-AMERICAN RELATIONS}

Abstract

The analysis aims to show the differences in the approach to the growth of communist China as perceived by Zbigniew Brzeziński and John Mearsheimer. It shows that the distinctly different attitudes of these thinkers to China's growth at the beginning of the 21 st century were getting closer over time. It happened as a result of the evolving position of Brzeziński, who gradually realized the danger America's consent and aid in China's enormous economic leap poses to the United States. That is why, towards the end of his life, Brzeziński began to write about the necessity to include Russia in the political body of the West, on the condition, however, that Vladimir Putin, whose authoritarian rule aims to recreate the fascist experiment in Italy, is removed from power.

Keywords: Zbigniew Brzeziński, John Mearsheimer, Sino-American relations, communism, liberalism, offensive realism, evolution of Brzezinski's position towards China, possibility of American-Chinese war. 


\section{Wstęp}

Wśród badaczy polityki międzynarodowej zgodnie przyjmuje się, że wzrost potęgi Chin jest jednym z najważniejszych wydarzeń definiujących XXI wiek. Pytanie, które z całą natarczywością nasuwa się w tym kontekście, brzmi: czy wspomniany wzrost, którego punktem dojścia miałoby być osiągnięcie przez Chiny statusu regionalnego hegemona, może przebiegać w sposób pokojowy? Osiągnięcie regionalnej hegemonii przez Chiny oznacza wyrugowanie amerykańskiej obecności i wpływów z Azji. Jednym z istotniejszych środków osiągnięcia tego celu przez Chiny byłoby zmuszenie USA do skoncentrowania się na sprawach terytorium, na których Stany Zjednoczone pozostają regionalnym hegemonem, czyli na obu Amerykach. Uniemożliwiałoby to, rzecz jasna, polityczne i militarne zaangażowanie USA w innych rejonach świata. Zakłada to wszakże ingerencję Chin w politykę toczącą się w państwach obu Ameryk. W tym kontekście zasadnicze pytanie brzmi, czy Stany Zjednoczone mogą tolerować mieszanie się Chin $\mathrm{w}$ politykę na terytorium, na którym pozostają regionalnym hegemonem oraz, przyjmując szerszą perspektywę, czy zgodzą się ustąpić w Azji pola Chińczykom, bez uciekania się do środka ostatecznego, jakim jest wojna? ${ }^{1}$

Oczywiście Stany Zjednoczone nie będą chciały prowadzić potencjalnej wojny z Chinami w pojedynkę. Będą starały się zbudować koalicję państw równoważących potęgę Państwa Środka, z ważną rolą Japonii, Indii, Australii, Wietnamu, Korei Południowej, Singapuru, być może też Rosji. W rzeczy samej proces ten już zachodzi. Wypróbowanej strategii powstrzymywania nie uda się jednakże przeprowadzić rękami samych sojuszników. Innymi słowy, potęga Chin stała się tak znacząca, że strategia powstrzymywania nie powiedzie się bez bezpośredniego zaangażowania Ameryki. Ponadto uczestnicy sojuszu są od siebie zbyt oddaleni, aby bez amerykańskiej koordynacji mogli z sobą skutecznie współdziałać. Amerykanie nie mogą zatem liczyć na to, co udało się w trakcie II wojny światowej, gdy pokonano Wehrmacht rękami przede wszystkim Armii Czerwonej.

W poniższej analizie zobrazuję dwie koncepcje rozwoju stosunków amerykańsko-chińskich. Pierwsza wyrażona jest przez Zbigniewa Brzezińskiego i wciąż do pewnego stopnia reprezentowana przez liberalne - w amerykańskim rozumieniu - elity, w tym przez prezydenta Joego Bidena. Druga znalazła eksponenta w osobie Johna Mearsheimera — profesora Uniwersytetu Chicagowskiego,

${ }^{1} \mathrm{~W}$ tym kontekście warto pamiętać o amerykańskich groźbach kierowanych pod adresem Rosji za mieszanie się w proces wyborczy w USA. Powtarzane są, także przez obecnego prezydenta Stanów Zjednoczonych, słowa, że Władimir Putin „zapłaci cenę” za ingerencję w wybory i wspieranie Donalda Trumpa. W słynnym już wywiadzie udzielonym George'owi Stephanopoulosowi Joe Biden zgadza się na określenie Putina mianem zabójcy, co jest wydarzeniem bezprecedensowym — tym bardziej, że nie może być ono traktowane jako coś przypadkowego. Zob. https://www.goodmorningamerica.com/news/story/biden-talks-cuomo-putin-migrants-vaccine-abc-news-76490303 (dostęp: 31.03.2021). 
czołowego orędownika teorii ofensywnego realizmu. Analiza Mearsheimera nie napawa optymizmem i wyraźnie ukazuje, że USA i Chiny znajdują się na kursie kolizyjnym, o ile Państwo Środka będzie nadal tak dynamicznie się rozwijać.

\section{Ewolucja stanowiska Brzezińskiego}

Nie ulega wątpliwości, że dla doradcy do spraw bezpieczeństwa narodowego za prezydentury Jimmy'ego Cartera zasadniczym przeciwnikiem USA był ZSRR. Po jego upadku chodziło zaś Brzezińskiemu przede wszystkim o zapobieżenie możliwości odrodzenia Rosji jako wielkiego mocarstwa. W tym kontekście ważnym czynnikiem przyczyniającym się do zwycięstwa Ameryki nad Związkiem Radzieckim był antysowiecki sojusz amerykańsko-chiński, zainicjowany przez duet Nixon-Kissinger, zaś odnowiony przez Brzezińskiego ${ }^{2}$. Współpraca między USA a Chinami przyniosła zatem obu państwom liczne korzyści, także po upadku ZSRR. Samemu zaś Brzezińskiemu pozwoliła na nawiązanie osobistych kontaktów z chińskim kierownictwem politycznym. Doświadczenie udanej współpracy wpłynęło bez wątpienia na przyjazny sposób postrzegania Chin przez Brzezińskiego, chęć włączenia ich w światowy krwiobieg gospodarczy. Przez bardzo długi okres Brzeziński uważał, że wzrost chińskiej potęgi — umożliwiony w dużej mierze przez Amerykę - nie będzie stwarzał zagrożenia z uwagi na gospodarczą współzależność państw. „Zarówno my, jak i Chińczycy wiedzą, że jeśli jedna strona uderzy w drugą, sama ucierpi”3. Tym samym był przekonany, że można uniknąć starcia, jakie w historii zazwyczaj następowało, gdy dotychczasowy hegemon musiał przeciwstawić się wzrastającej potędze.

Wydaje się jednak, że w miarę upływu czasu optymizm Brzezińskiego w odniesieniu do relacji amerykańsko-chińskich malał. Siłą rzeczy niełatwo jest rewidować swój stosunek do kraju, z którym sojusz przyniósł bardzo wymierne korzyści — $\mathrm{w}$ dalszym ciągu chciałoby się go mieć u swego boku, jeżeli nie cały czas, to przynajmniej w najbardziej newralgicznych momentach. Stopniowo jednak ciężar faktów czynił coraz trudniejszym zadanie przechodzenia do porządku dziennego nad realną konkurencją Chin.

${ }^{2}$ Brzeziński przypomniał o tym w dyskusji, która odbyła się 16 listopada 2011 roku w ramach National Commitee On United States-China Relations, https:/www.youtube.com/watch?v=fnia12JO7AU (dostęp: 1.04.2021).

3 Brzeziński w wywiadzie z Jeffreyem Brownem, 9 lutego 2012 roku, https://www.youtube. com/watch?v=2dR6PrcsOpc (dostęp: 1.04.2021). Syn Zbigniewa Brzezińskiego, dyplomata Mark Brzezinski, w 2019 roku wciąż twierdził, że jego ojciec podtrzymywałby tezę o korzyściach płynących ze współpracy gospodarczej i braku zagrożenia ze strony Chin. Wydaje się, że przeocza on fakt stopniowej zmiany stanowiska ojca. Cytowana wypowiedź Zbigniewa Brzezińskiego, w której mówi on nie tylko o Rosji, ale także o Turcji jako możliwej części Zachodu, ma na celu wzmocnienie Zachodu właśnie w konfrontacji z Chinami. 
Ciekawą i pouczającą rzeczą jest przeanalizowanie owej ewolucji Brzezińskiego — od obrony polityki amerykańskiej, umożliwiającej Chinom awans gospodarczy, do uświadomienia sobie, że Chiny stanowią jednak zagrożenie i należy zbudować koalicję, która stanęłaby na przeszkodzie dalszej ich ekspansji oraz przełożeniu chińskiej potęgi gospodarczej na militarną i polityczną. W dyskusji między Brzezińskim a Mearsheimerem, opublikowanej w Foreign Policy w 2005 roku (sama dyskusja odbyła się w rok wcześniej), stanowisko tego pierwszego jest klarowne: Chiny są nade wszystko zainteresowane rozwojem ekonomicznym, nie dążą do rzucenia rękawicy USA pod względem wojskowym, konflikt chińsko-amerykański nie jest nie tylko nieunikniony, ale nawet prawdopodobny. „Chiny - twierdził Brzeziński — pragną za wszelką cenę utrzymać swój wzrost gospodarczy. Konfrontacyjna polityka zagraniczna mogłaby ów wzrost narazić na szwank, boleśnie dotknąć setki milionów Chińczyków i zagrozić utrzymaniu władzy przez Partię Komunistyczną"4. Jego, prezentowanym wówczas, zdaniem, Chiny nie stanowią dla Ameryki zagrożenia militarnego. „Czterdzieści lat po uzyskaniu broni jądrowej Chińczycy mają tylko dwadzieścia cztery pociski balistyczne zdolne do uderzenia w terytorium Stanów Zjednoczonych" ${ }^{\text {. Państwo }}$ Środka to także kraj, który Stany Zjednoczone mogłyby łatwo zablokować i odizolować: „W razie konfliktu chiński handel morski zostałby całkowicie wstrzymany. Ustałby dopływ ropy naftowej i cała chińska gospodarka zostałaby sparaliżowana"6. Brzeziński dopuszczał myśl, że gdyby społeczno-polityczne napięcia lub społeczne nierówności stały się nie do opanowania, chińskie władze mogłyby zagrać kartą nacjonalistyczną. Jednak prawdopodobieństwo takiego obrotu spraw uważał za niewielkie. Wierzył, że uda się uniknąć negatywnych następstw związanych z pojawieniem się na scenie nowej potęgi.

Nie chcąc poddać się dyktatowi Mearsheimerowskiej teorii realizmu ofensywnego, która skazywałaby USA i Chiny na konfrontację, z wojną włącznie, Brzeziński twierdził, że teorie w stosunkach międzynarodowych mają charakter retrospektywny. Oznacza to, że teoria ulega modyfikacjom za każdym razem, gdy wydarza się coś, co do niej nie przystaje. Co więcej, teorie zbudowane na materiale empirycznym zaczerpniętym z przeszłości (tak jest w przypadku realizmu ofensywnego) nie biorą pod uwagę, do jakiego stopnia broń nuklearna zmieniła bieg dziejów, wpływając na możliwość zaistnienia konfliktów. Ponadto wedle Brzezińskiego zachowanie państw nie jest z góry określone. Przykładowo, Japonia w 1941 roku mogła skierować swoją ekspansję w stronę Rosji, nie zaś Wielkiej Brytanii i USA, a wówczas jej losy mogły potoczyć się inaczej. Brzeziński nie widział również sposobu, w jaki Chiny mogłyby pozbyć się amerykańskiej obecności w Azji. Nawet zresztą gdyby Chińczykom w jakiś sposób ta sztuka się

4 Z. Brzeziński, J.J. Mearsheimer, Clash of the Titans, https://foreignpolicy.com/2009/10/22/ clash-of-the-titans/ (dostęp: 1.04.2021).

5 Ibidem.

6 Ibidem. 
udała, to w konsekwencji Japonia szybko wyprodukowałaby broń jądrową, rozwinęła pozajądrowy program zbrojeń i wybudziła uśpiony japoński nacjonalizm. Brzeziński wątpił, by taki scenariusz odpowiadał chińskim władzom.

Znaczące jest, że ze Strategicznej wizji, opublikowanej w 2012 roku, a więc osiem lat po wspomnianej dyskusji opublikowanej w Foreign Policy, wyłania się już inny obraz Chin i relacji chińsko-amerykańskich. Nie ulega wątpliwości, że Brzeziński pozostawał pod wrażeniem rozwoju Państwa Środka. Porównanie infrastruktury Chin i USA wypada jednoznacznie na korzyść Chin. Najistotniejsze wszakże, z punktu widzenia prowadzonych rozważań, jest zawarte tam stwierdzenie Brzezińskiego, że Rosja powinna zostać włączona do politycznego i gospodarczego systemu świata zachodniego, jednak pod warunkiem, że na jej czele nie będzie stał Władimir Putin ${ }^{7}$. Amerykański polityk stwierdza explicite, że

Europa to dziś wciąż niedokończony projekt. I pozostanie nim, dopóki Zachód w sposób strategicznie trzeźwy i rozważny nie przyjmie do swego grona Turcji na bardziej równych warunkach oraznie otworzy się politycznie i gospodarczo na Rosję. Taki rozszerzony Zachód może pomóc zakotwiczyć stabilność ewoluującej Eurazji [wyr. - P.K.] ${ }^{8}$.

Zatem niedługo przed śmiercią Brzeziński zaczął dopuszczać myśl o Rosji jako aliancie w koalicji antychińskiej. Jej udział w niej wydaje się, rzecz jasna, trudny do przeceniania, byłby to czynnik prawdopodobnie przesądzający wynik zmagań chińsko-amerykańskich. Czy jednak jest on możliwy? Rosjanie, co oczywiste, obawiają się nie tylko zdominowania przez Amerykanów świata, ale także wzrostu chińskiej potęgi - tym bardziej, że długość ich granicy z Chinami wynosi ponad cztery tysiące kilometrów. Przykładowo rosyjskim władzom do myślenia musi dawać coraz poważniejsza obecność Chińczyków na Syberii. Jak stwierdził szef moskiewskiego Instytutu Analiz Politycznych i Wojskowych Aleksander Chramczichin: „Tylko naiwni mogą mówić o rosyjsko-chińskim partnerstwie strategicznym. Pekin potrzebuje zasobów naturalnych i terytorium. Granica zostałaby przekroczona, gdyby Rosja osłabła, a w Chinach doszłoby do poważnego kryzysu, który wymagałby ekspansji zewnętrznej"9. Z drugiej jednak strony, uwagi nie powinny uchodzić bardzo złe stosunki Rosji ze Stanami

7 „Niestety Putinowska wizja przyszłości opiera się na wstecznej kombinacji wojowniczego nacjonalizmu, niemal nieskrywanej wrogości do Stanów Zjednoczonych w związku z ich zwycięstwem w zimnej wojnie oraz tęsknoty zarówno za nowoczesnością, jak i powrotem do statusu supermocarstwa (sfinansowanym, zgodnie z jego nadziejami, przez Europę). Państwo, jakie ma nadzieję zbudować, uderzająco przypomina faszystowski eksperyment we Włoszech: wysoce autorytarne (ale nie totalitarne) rządy opierające się na symbiotycznym związku elity władzy z oligarchią biznesową, kierujące się ideologią niemal nieskrywanego, pompatycznego szowinizmu"; Z. Brzeziński, Strategiczna wizja. Ameryka a kryzys globalnej potęi, przeł. K. Skonieczny, Kraków 2013, wersja mobi, loc 3186-3192.

8 Ibidem, wersja mobi, loc. 2852.

9 Wypowiedź dla dziennika „Rzeczpospolita”. Zob. https://www.rp.pl/Polityka/307029903-Syberia-nie-obroni-sie-przed-Chinami.html (dostęp: 31.03.2021). 
Zjednoczonymi i Europą, których najdobitniejszym potwierdzeniem są nałożone przez Zachód na Rosję sankcje gospodarcze. Nie ulega wątpliwości, że władze w Pekinie nie posunęłyby się do pouczania Rosji w zakresie poszanowania praw człowieka, sposobu traktowania opozycjonistów politycznych, wyparcia demokracji liberalnej przez „demokrację sterowaną”, czyli w skrócie do kwestionowania rządów Putina, gdyż naraziłyby się wyłącznie na śmieszność. W tym świetle nadzieje Pekinu na polityczne pozyskanie Rosji lub na neutralność Rosji w sporze z USA mają pewne uzasadnienie.

Oczywiście w samych Stanach Zjednoczonych obok zagorzałych przeciwników Rosji istnieją przedstawiciele środowisk intelektualnych i politycznych, którzy pracują na rzecz poprawy stosunków amerykańsko-rosyjskich ${ }^{10}$. Jednym z nich jest John Mearsheimer. Podstawowym według niego problemem polityki amerykańskiej jest wzrost potęgi Chin. Kluczową kwestią w przezwyciężeniu tego problemu jest obecność w amerykańskim obozie sojuszniczym Rosji. W tym kontekście rozpatrywać można wykładowe tournée Mearsheimera po świecie, w którym przekonywał, że to Zachód — nie zaś Rosja — ponosi odpowiedzialność za aneksję Krymu ${ }^{11}$.

\section{Wizja Mearsheimera}

Swoją nienapawającą optymizmem analizę rozwoju stosunków amerykańsko-chińskich Mearsheimer wypowiadał przy wielu okazjach. W skróconej wersji zawarta jest ona w przywołanej dyskusji z Brzezińskim. Najpełniej Mearsheimer wypowiedział się $\mathrm{w}$ rozdziale dołączonym do najnowszego wydania jego Tragizmu polityki mocarstw, zatytułowanym Czy wzrost potęgi Chin doprowadzi do wojny? Rozdział ten znajduje się również w polskim wydaniu Mearsheimerowskiego opus magnum. Argumenty amerykańskiego badacza zbudowane są, jak wiadomo, na teorii ofensywnego realizmu. Na jej gruncie państwa, w tym także mocarstwa, są zdeterminowane do określonych działań i zachowań przez samą naturę systemu międzynarodowego, w którym nadrzędnym celem aktorów-państw jest przetrwanie. System ten jest anarchiczny (w tym sensie, że nie jest hierarchiczny — nie istnieje arbiter nadrzędny wobec woli państw, a zatem państwa w ostateczności mogą liczyć tylko na własne siły), każde państwo — także

10 Jednym z najważniejszych spośród nich był zmarły w zeszłym roku Stephen F. Cohen sowietolog, wykładowca między innymi Princeton University. Por. jego ostatnią książkę War with Russia? From Putin and Ukraine to Trump and Russiangate, New York 2019. W słynnym artykule opublikowanym w „The Nation” 3 marca 2014 roku Cohen stwierdził, że „amerykańskie media w sprawach Rosji są dziś mniej obiektywne, mniej wyważone, bardziej konformistyczne i niewiele mniej ideologiczne niż w czasach zimnej wojny".

11 Zob. J.J. Mearsheimer, Why the West - Not Putin - Is Responsible for the Ukraine Crisis. Jeden ze swych wykładów na powyższy temat Mearsheimer wygłosił w Uniwersytecie Jagiellońskim w 2016 roku. Zob. https://www.youtube.com/watch?v=1ZrNhmdHzY4 (dostęp: 31.03.2021). 
słabe — ma w nim możliwość wyrządzenia szkody innemu, państwa nie mogą być pewne przyszłych intencji innych oraz zakłada się, że działają racjonalnie. $\mathrm{Z}$ tak zarysowanego systemu wyłania się strach, jaki państwa wzajemnie do siebie odczuwają oraz dążenie do potęgi, bo tylko jej kumulacja zwiększa szanse zrealizowania nadrzędnego celu, jakim jest przetrwanie ${ }^{12}$. W ujęciu Mearsheimerowskiej teorii Chiny nie są wyjątkiem i będą działały zgodnie z logiką tego systemu. To oznacza, że będą chciały zdobyć pozycję regionalnego hegemona, czemu z kolei musi się przeciwstawić jedyny istniejący hegemon regionalny Stany Zjednoczone Ameryki.

Dlaczego Chiny miałyby zachowywać się inaczej niż Stany Zjednoczone? Czy Chińczycy są moralnie wyżsi od Amerykanów? Mniej nacjonalistyczni? Mniej zainteresowani własnym przetrwaniem? Większą wagę przywiązują do zasad? Rzecz jasna we wszystkich tych przypadkach odpowiedź brzmi: nie. Z tych właśnie powodów twierdzę, że Chiny podążą ścieżką wytyczoną przez elementarną logikę realizmu i podejmą próbę zdominowania Azji ${ }^{13}$.

Wyraźnie widać, że autor Dlaczego politycy kłamią? nie wierzy, że konfucjańska kultura, w której zanurzone są Chiny, zapobiegnie współzawodnictwu między Państwem Środka a sąsiadami i Stanami Zjednoczonymi. Według niego konfucjanizm dla Chińczyków jest tym, czym liberalizm dla polityków amerykańskich - narzędziem kamuflażu pozwalającym kreować się na idealistów, podczas gdy w rzeczywistości działają w myśl zasad Realpolitik. Wedle Mearsheimera ryzyko wybuchu ograniczonej wojny między koalicją zbudowaną przez USA a Chinami jest większe aniżeli ryzyko wybuchu wojny między dwoma supermocarstwami w okresie zimnej wojny. Nie są w stanie jej powstrzymać powiązania gospodarcze, ponieważ polityka jest istotniejsza od ekonomii i, co za tym idzie, „kwestie bezpieczeństwa niemal zawsze biorą górę nad interesami ekonomicznymi" ". Chicagowski badacz przypomina, że przed I wojną światową państwa europejskie także były ze sobą powiązane ekonomicznie i przeżywały okres prosperity, ale nie zapobiegło to wybuchowi wojny. Możliwość wybuchu w Azji wojny między mocarstwami potęguje geografia tego kontynentu oraz wytworzenie się systemu zachwianej wielobiegunowości (zachwianej, gdyż Chiny będą przewyższać potęgą wszystkie inne państwa regionu).

W układach wielobiegunowych istnieje więcej potencjalnych par konfliktu [...], większa liczba graczy sprawia, że trudniej o równomierny rozkład potęgi [...], istnieje większe ryzyko błędnej kalkulacji [...], państwom łatwiej jest zmieniać sojusze oraz przerzucać się nawzajem odpowiedzialnością [...], potencjalny hegemon wzbudza większy niepokój wśród rywali, co popycha ich do przyjmowania ryzykownych strategii, które mogą doprowadzić do wojny ${ }^{15}$.

12 Zob. J.J. Mearsheimer, Tragizm polityki mocarstw, przeł. P. Nowakowski, J. Sadkiewicz, Kraków 2019, s. 5-16.

13 Ibidem, s. 444.

14 Ibidem, s. 464.

15 Ibidem, s. 472. 
Do wszystkich powyższych czynników należy doliczyć jeszcze jeden, który znacząco zwiększa prawdopodobieństwo konfliktu. Jest nim chiński nacjonalizm, który ma także charakter oddolny. Oznacza to, że jest on autentyczną, nie zaś odgórnie sterowaną, postawą bardzo wielu Chińczyków. Świadomość stulecia narodowego upokorzenia (1839-1949) jest wśród nich rozpowszechniona. Podobnie jak rozpowszechnione jest pragnienie rewanżu, pomszczenia czasów, kiedy to szlachetne Chiny stały się ofiarą drapieżnych mocarstw, ze Stanami Zjednoczonymi na czele.

\section{Konkluzje}

Jeśli przyjmiemy, że chicagowski badacz ma rację, to w dwuznacznym świetle stawia on część amerykańskich elit politycznych, w tym oczywiście i Brzezińskiego. Ich działania okazały się bowiem na tyle krótkowzroczne, że umożliwiając Chinom skok gospodarczy, między innymi przez włączenie ich do Światowej Organizacji Handlu w 2001 roku — za czym optował obecny amerykański prezydent Joe Biden - nie przewidziały dalekosiężnych konsekwencji swoich działań. Pojawia się oczywiście pytanie, czy można było zapobiec spektakularnemu i niebezpiecznemu dla USA rozwojowi Chin. Z pewnością było to zadanie niezwykle trudne. Wydaje się jednak, że w mocy Ameryki leżało znaczące spowolnienie tego procesu.

Wizja Mearsheimera jest odmalowana w ciemnych barwach. Jego teoria ma wszakże silne podstawy i ignorowanie jej na tej tylko podstawie, że jej odbiór nie sprawia przyjemności, byłoby poważnym błędem. W pełni świadomi są już tego amerykańscy decydenci polityczni bez względu na przynależność partyjną, jako że strategia powstrzymywania Chin jest już od pewnego czasu wdrażana. Informacje o wielu podejmowanych działaniach nie docierają zapewne do opinii publicznej, stanowiąc przedmiot zabiegów zakulisowych. Jednak te, o których słychać, nie pozostawiają w tej kwestii wątpliwości.

Zasadniczą wątpliwość rodzi natomiast pytanie, czy amerykańska reakcja nie następuje zbyt późno: czy Mearsheimerowski głos, który dziś jawi się jako dość oczywisty, nie był zbyt długo ignorowany ${ }^{16}$. Część amerykańskich polityków (w tym Brzeziński i obecny prezydent Joe Biden) nie przewidzieli, że podarowanie tak utalentowanym ludziom jak Chińczycy czterdziestu lat swobodnego rozwoju spowoduje nie tylko to, że Chiny wejdą w gospodarczy krwiobieg świata (przez to staną się, jak liczono, przewidywalną częścią porządku światowego), ale wyrosną na realną konkurencję dla Ameryki. Staną się państwem, które może pokusić się o regionalną hegemonię w Azji Wschodniej, państwem o ogromnych

16 Gwoli ścisłości należy dodać, że w datowanym na 2001 rok pierwszym wydaniu Tragizmu polityki mocarstw kwestia chińska nie jest postawiona w należyty, dosadny sposób. Dopiero trzy lata później Mearsheimer dostrzegł i zaczął opisywać chińskie niebezpieczeństwo dla Ameryki. 
wpływach w skali globu, których powstrzymanie będzie arcytrudnym, o ile w ogóle możliwym do wykonania, zadaniem.

\section{Bibliografia}

Biden J., Wywiad z Georgem Stephanopoulosem, https://www.goodmorningamerica.com/news/story/biden-talks-cuomo-putin-migrants-vaccine-abc-news-76490303.

Brzeziński Z., Strategiczna wizja. Ameryka a kryzys globalnej potęgi, przeł. K. Skonieczny, Kraków 2013.

Brzeziński Z., Wystąpienie w ramach National Commitee On United States-China Relations, https://www.youtube.com/watch?v=fnia12JO7AU.

Brzeziński Z., Wywiad z Jeffreyem Brownem, 9.02.2012, https://www.youtube.com/watch?v=2dR6PrcsOpc.

Brzeziński Z., Mearsheimer J.J., Clash of the Titans, https://foreignpolicy.com/2009/10/22/clash-of-the-titans/.

Chramczichin A., Syberia nie obroni się przed Chinami, https://www.rp.pl/polityka/art1868281-syberia-nie-obroni-sie-przed-chinami.

Cohen F., Media Malpractice. Putin, Sochi and Ukraine, „The Nation” 3.02.2014.

Cohen F., War with Russia? From Putin and Ukraine to Trump and Russiangate, New York 2019.

Mearsheimer J.J., Tragizm polityki mocarstw, przeł. P. Nowakowski, J. Sadkiewicz, Kraków 2019.

Mearsheimer J.J., Why the West - Not Putin - Is Responsible for the Ukraine Crisis, https://www. youtube.com/watch? $\mathrm{v}=1 \mathrm{ZrNhmdHzY} 4$. 